\title{
New Contexts for the Transmission of Sacred Knowledge: A Case Study from the Carpathian Mountains ${ }^{1}$
}

\author{
Laura Jiga Iliescu \\ "Constantin Brailoiu" Institute of Ethnography and Folklore of the Romanian Academy (Bucharest); \\ "East-West" ERC Research Group, Institute of Ethnology, RCH, \\ Hungarian Academy of Sciences, Budapest
}

\begin{abstract}
This paper inquires about the social reasons and epistemological consequences of sacred knowledge (charms) outside its "original setting", toward an archive of folklore or to a new age journal. Some local specificities of relationships between knowledge and power are explored through multiple contextualisations of an interview we conducted with a former shepherd and healer in the Carpathian Mountains, Romania.
\end{abstract}

Keywords: charm, serpent, shepherd, Carpathian culture, New Age culture

"There are hardly any shepherds who cannot say charms or cast spells, especially if they are elderly males" (MARIAN 1875:357). This study concerns such an old man and his $21^{\text {st }}$ - century survival.

\section{FOLKLORE DOCUMENT AND THE SACRED}

When we record a certain folkloric piece which has a ritual function in its natural setting, we generally do not expect that its numinous power will be preserved outside, during its second life (Honko 1998:108). On the contrary, we behave as if it loses any sacred component once turned into a document stored on shelves or in precious boxes, from which different scholars may bring it out, listen to it and then put it back, each having a specific attitude toward its original status and function. But informants do not necessarily

\footnotetext{
${ }^{1}$ The research leading to these results has received funding from the European research Council under the European Union's Seventh Framework Program (PG7/2007-2013)/ERC grant agreement No. 324214, Vernacular religion on the boundary of Eastern and Western Christianity: continuity, changes and interactions; in the framework of the Institute of Ethnography and Folklore, Constantin Brailoiu's project Contemporary religiosity in Romania; and in the context of a collaboration with Mioritics Tourist Agency and the Sibiu Tourist Office.
} 
share our ideas over the subjective and relative character of the ritual power and they may consider it absolute and unquestionable. This is why our informants sometimes allow us to record such pieces, but not at other times, each situation having its own mechanisms, meanings and consequences.

The tensions between the etic (e.g. sacred is a concept, a cognitive or aesthetic category of social reality) and the emic (the sacred is a vivid and fundamental component of reality) perspectives are not wound down by avoiding the differences, but possibly through an understanding of how the two approaches over the same reality could relate to one another.

\section{THE STORY}

Being interested in the connection between folk religiosity, the configuration of mountainous space and local professional expertises, in 2014 I conducted field research in the Cindrel Mountains (South Carpathian Mountains, Romania) and in the Mărginimea Sibiului area, famous for its intense pastoral activity, including the practice of transhumance. Here I met D. Ș. He was born in 1924, in village G. R., in a family whose members "have been shepherds for generations". Still attached to its pastoral profile, the village opened its gates to rural tourism as well. Besides the economic impact of this new life, the changes that have occurred in recent years are linked with this specific context/frame of intercultural contacts, regarding the (local and foreign) attitudes towards the past and tradition as well. Things are working quite well, and D. Ş. takes part in these new challenges at his turn.

The main reason I wanted to meet D. S.. was to talk with him about mountains, borders, narratives about meeting with supra-natural beings, rites and pastoral practices. In the time spent together, stories, comments and gestures shaped the profile of an intelligent and communicative man; proud, quite humorous, religious, a bit cautious and a bit shy, somewhat difficult to catch, and a fine story teller. He was the head of the mountain for 40 consecutive years, chief of all the state-owned sheepfolds. Such a position requires special physical, moral and mental abilities, as well as the quality of being the bearer of professional shepherding knowledge related to zoology and ethology, gastronomy, meteorology - "the sign of the times" - astronomy and spatial orientation, topography, arithmetic, legislation and, last but not least, a repertoire of ritual and empirical therapeutic practices. D. S. possesses all of these qualities at the age of 90 and was respectfully referred to by locals as Babu (meaning father, chief). People in the village said that D. S. knows a lot, an ambiguous phrase which combines admiration, recognition of authority and a trace of mystery, because not just anybody knows what he knows.

D. S. spent most of his childhood among shepherds. According to his autobiographical story (which I did not check with the other villagers), when he was 16 years old, he healed an ox and thus became known as a healer within the local and professional community. He continued healing not only animals, but humans as well, and this is the most important quality that he assigned to himself. Actually, the first words he said when saw us were: "No matter what might hurt you, just tell me, and I'll help you." This somehow unexpected situation reshaped the interview, and so therapeutic issues came to be included among the topics of discussion. 
In this regard, I became interested in what D. S.. meant by therapeutic act, asking myself the following questions: How does he define himself on light of the authority of knowledge that he bears and transmits? What value does it have for him? What are the circumstances when he agrees to use this special type of knowledge and skills, and how are all these connected with shepherding and with his position? What does tradition signify to him? What does an outsider mean to him?

This article aims to articulate an answer that will integrate the questions above in order to catch some aspects linked with the contemporary dynamic of traditional knowledge and of attitudes towards sacredness, namely the alterations of functions that a certain charm and narrative suffer while transmitted through different means, within different contexts, including an archive of folklore or a mass media journal.

One case study will be presented here, one which will not serve as the basis for assumptions ready to be mechanically extended to the entire phenomenon integrating the topic of our study. However, as a result of successively examining different contexts (genetic and generic, social, political and religious), we will be able to make an extended set of general remarks regarding the status of sacred knowledge, of the secret and of those who know in our times, when (even) traditional society is adjusting to new paradigms of disseminating information, characterized by widely spreading any type of data, by promoting anybody's unlimited access to any type of knowledge, anywhere.

- (...) Long time ago there were no remedies, there were plants! (...) When you see [your sheep - L.J.I.] are not well, you make some bran, take it to the priest, he does this... then, you give it to the sheep to eat. There are sheep ... you see them how they lower their ears and stop eating and they're hungry. "Whoops! Evil eye!"

- Evil eye you said?

- There are [people] with evil eye.

- What do you do when you see this?

- Well, you mumble, you grumble.

- What are you mumbling?

- Well, not all secrets can be told.

- How shall I find them out if you aren't telling me?

- Let me tell you something. Have you ever gone to a priest to confess?

- Yes, I have.

- Did you tell him everything then?

- [pretends she hasn't heard the question] Apart from that mumbling that we don't want to find out, what else do you do? Do you burn something around them...?

- You say something.

- Aloud?

- Mmm... [a few seconds of silence]

- But were there any charms to bring back the [magic] stolen of the sheep's milk?

- I don't want to learn those any longer.

- But there were some charms?

- [after a few seconds of silence, he started to narrate] 'Cause the sheep were there, from one side of the mountain to the other. They said: "Bring here the polenta caldron" (...) And stabbed the fir tree with a knife. And put the cauldron. Stole the milk. And if the sheep were barren, it was blood streaming out. And if you didn't know what to do, all of them would 
die. And I hired a shepherd. I was - above the shepherds it was somebody called head of the mountain - for 40 years the head of the mountain was me (...). And I hired a shepherd I didn't know [he sighs]. And I felt that he...knows something. When I hired him, he asked me which my sheep mark is. And I told him how they are marked. "Who else is watching the sheep with you?" I said: "My brothers". "Which are their marks?" "This and that." Good. Each summer three, four of the sheep die. And he went to the barren ones. These are sent out to graze on a higher level, on a peak. And I was working in the hayfield, near Păltiniş. (...) A hut, like this, a hut. (...). And, my shepherds called me [up] there, as I had more sheep and I had to take the cheese. (...) I left my wife at the lower sheepfold and mounted the horse and set off. I went there and the shepherds were waiting for me. The shepherds said: "Bade, the ones from the barren sheep, wretched lot. They have some bad sheep. And (...) there is an unclear thing there; the new one, they said, the one that you've just hired, he is not good". I didn't say anything. (...). "Don't worry, I'll see to it." We started to take the cheese. It was the shepherd there and one more person. And we left the horses in the field. And that one from up there, he saw the horses at the sheepfold. He said: "Oi, Ș. has come. The boss came". I just saw him. [And he said:] "You, Babu, have you come?" "I have." "Come to the sheep, come and look at the sheep. Your men mock me and I am going to kill somebody!" "Don’t be stupid! Can't you just get on well for three months? What do you want? Do you want to go to prison? Don't you like to be free? Ok, I'm coming. Just to put the cheese in." [explaining to us] I was being cunning. (...) - to put the cheese in to run down the mountain. But he, more cunning than me, said: "I'll stay here to help you." We put the cheese in and when we finished, "Let's go now." I left. (...) The others, the shepherd and the others said: "We're also leaving, Babu D." "All right, lads." Walking back ... I saw he knew something. To hear what he was mumbling, those words I was interested in, I went up to a certain place. There the path branched off. "This guy", I said, "is going to Tică's hut. And this other path takes us up the hill to Niculiță's place, where the hunters shoot wood grouses. Ion, would you like to see it?" He said: "I would, Babu." "You'll see where they shoot them, I'll show you the wood grouses and the two of us will walk this way and the others walk the other way. The first one who reaches Tică's hut should give us a loud shout." And I left with this guy. And we walked. Here, up the hill, at Niculiță's place, there were no more fir trees and we walked across that clearing. And I said: "You, Ion, when you stab the fir tree with a knife and blood streams down.... and if you don't know what to do, the sheep will die...". He said: "I don't know anything". "Hey!! I don't need anything but the words! I turn the lamb coat inside out and beat it with my crook as strongly as I can, and (...) the one who harmed the sheep, feels the pain.” And [explaining for us - L.J.I.] you need the kid of an un-yeaned goat (...) You need its skin. He says: "You know more than me." "Hey, Ion, just tell me the words!" He was walking ahead and I followed him. He had a crook as thick as a man's arm and I had just a thin one like a broomstick. And I kept asking him to tell me the words. Then I couldn't take any steps: snakes surrounded me! God is above us and He hears if I lie! And what snakes! With hairy heads, so hairy that they couldn't see! And they stood up on their tail, as tall as me, and stuck out their tongues, to bite me. I waved my hands and couldn't take any steps forward. If I was standing like this [he shows us that he was standing still - L.J.I.], they were down. If I was moving, they were making a sssssshuuuu sound. "Hey, Ion, hey!" I was shouting; he was as far as that gate is now. He sat down. Me: "Hey, Ion! Come, dear! Give me your crook!" "What do you want to do with it? Don't you dare to kill any of them, 'cause you'll not see another good day in your life!”. I crossed myself and...said to myself: "I'm travelling with the devil”. Each time I moved, the snakes were standing on their tails to bite me! I cried out to the other shepherds: "Hey! 
Come down here, hey you!" This one saw that it wasn't a joke. "Hey, Ion, give me your crook!" "What to do with it?" "I want to take the crook, jump over, to run away from here!" He came over there and gave me his crook. I didn't attack and hit any snakes to see what happened. I just waved the crook as if I had mowed. And when I did it, there was ...only dust. And all around, no snakes. He asked: "Where? What did you see? You didn't see anything." "You, I said, you are not clean". And I went away. (...)

And it was another shepherd together with this Ion. When I got there, I've never seen such sheep. Black wool and good and nice. "Where do you take them to graze? Where do they eat?" He says: "For a week now we've been walking on all the mountains, we're afraid of nobody." And in the autumn, from all the flock, only two sheep of mine there were missing. And the one who had a quarrel with him [with the outlander - L.J.I.] had only few sheep left in the autumn; they would die one after the other.

- Well, this boy protected your sheep a bit.

- He protected them, but he didn't do good things; he did devilish things. Since then, I've never wanted to ask about those mumbled words.

- Where did he go to then? Did he leave this place or stay with other shepherds?

- He went away. He was from another village. In Jina. All sorts of people.

- Have you ever met somebody, not necessarily a person, on the road?

- [with tears] Don't ask me all these things.

- All right.

- I once took my cart through a forest. And there were low branches and I had to duck my head. And I see a woman at the side of the road. (...).

He went on telling us another memorate about Good Friday. The dramatic core of the narrative above is represented by the transmission of the words of the therapeutic charm meant to recover the barren sheep, collateral victims of the spell for milk stealing. However, the entire message of the memorata (not only what Babu D. Ș. says but also to whom, why and what he means when he says what he says) is less obvious and is shaped by many layers - the text, the meta-text and the para-text - which also includes us, the fieldworker, in the transmission of the charm, along with the two characters directly involved in the events. We have included the transcription of the story in the discussion which triggered it (the evil eyes), because, as we will mention further, this very beginning helps to build the message. The entire interview (30 pages long) cannot be transcribed here but, when necessary, we will quote some other excerpts. The document can be found in the Archive of the Ethnography and Folklore Institute (AIEF), Information Fund, no. I. 34883.

Therefore, we will start from the fragment transcribed above, which will be integrated into the entire interview, then into the performance event, which in turn will be seen as part of a series of events prior to our field work. 


\title{
THE CONFRONTATION
}

\section{Shepherd's Crook}

It is a crucial element in the props of any shepherd, used as weapon against wild animals and humans, as a stick for travelling, as support for the standing body, and as mark of the owner's identity. In order to decode Babu's message, we have to reintegrate the story into the larger system of folk beliefs, at their turn expressed through legendary narratives. In this regard, its essential role in the narrative quoted above is to mark the fundamental difference between the two opposing characters: one is placed under the sign of magic, while the other chooses God's authority. Allow me to explain this statement interpretation with a fragment from Exodus, Chapters 4 and 7 :

"The Lord said to him [to Moses], 'What is that in your hand?' And he said, 'A staff.'

Then He said: 'Throw it on the ground!' So he threw it on the ground, and it became a serpent. And Moses fled from it. But the Lord said to Moses: 'Stretch out your hand and grasp it by its tail.' So, he stretched out his hand and caught it, and it turned back into the staff in his hand" (Exodus, 4:2-5). "Later the Lord said: 'And you shall take this rod in your hand with which you shall work the signs'.” (Exodus 4:17).

It should be considered as fact that, at that moment, Moses was a shepherd; hence he was holding a shepherd's crook, which God endowed with miraculous power! Later:

\begin{abstract}
"So Moses and Aaron went to Pharaoh and did just as the Lord commanded. Aaron cast down his staff before Pharaoh and his servants, and it became a serpent. Then Pharaoh summoned the wise men and the sorcerers, and they, the magicians of Egypt, also did the same by their secret arts. For each man cast down his staff, and they became serpents. But Aaron's staff swallowed up their staffs." (Exodus 7:10-11)
\end{abstract}

At least for the Orthodox milieu (to which $B a b u$ belongs), the popularity of this episode derives from the fact that, alongside the Biblical text, it is inserted in sermons, one of them being The Sunday of the Thin Man.

Tangentially relevant to our topic, we would like to mention a belief recorded in the Eastern Carpathians Mountains, in Valea Bistriței: "The shepherd thought that his arm is powerful only when he is holding the crook adorned with the figure of a serpent. At night, before going to sleep, he would say the same charm and make the sign of the cross because he was afraid that if he didn't do so, the serpent could escape from his power, free itself, turn into a dragoon (Ro balaur) and eat the sheep" (Prut 1972:32). Such a crook was not and is not a common object and we do not think that anybody can have one. In our story, no serpents carved on Ion's bludgeon are mentioned. However, D. S.. remarked the difference in status, mirrored by the difference in the proportions of the two rods

\footnotetext{
${ }^{2}$ We use the translation available on www.biblegateway.com.
} 
- He had a crook as thick as a man's arm and I had just a thin one like a broomstick - and that only Ion's staff had power over the serpents.

However, Ion's real identity as a powerful wizard (which was hidden at the profane level), was revealed by his very bludgeon, which turned into a sign of power.

Therefore, the confrontation between Aaron and the sorcerers is relevant to our story because D. S. had two options: the magic authority (represented by the Biblical sorcerers and in our story by Ion, whose power is illusory, considering that the snakes turn into dust), and the religious one (represented by Aaron, whose snake swallows the sorcerers' snakes). Apparently, D. Ș. chose the latter one: "God is above us, so help me God. (...) I made the sign of the cross and ... I said: 'I'm travelling with the devil!'," (We will return to this aspect later).

\section{D. S.'s failure as a knowledge receiver and the meaning of the serpents' appearance. The hidden spell}

Considering that the efficiency of the ritual is ensured by a functional systemic relation between gestures, verbal structures, props, performers and rules of space and time, D. Ș. knew very well that without the words, the bomboroaie, the scenario would not work. The very words that he requested represented a form of sacred knowledge placed under the interdiction of explicitly transmitting them or revealing the verbal structures only in ritually conditioned contexts.

Ovidiu Bîrlea wrote:

\footnotetext{
"The ritual practice recommends learning the charm by stealing it, by spying on the one who is performing it for you, which seems to be linked with its numenal efficiency. It is known that its efficiency is annihilated when the charm is told to somebody else, and some even have punitive effects, turning the evil thing against the charmer who dared to break the interdiction of the secret. (...). Such numenal virtue is guaranteed firstly by the mystery veil which covers all its forms of manifestation, starting with its indirect, clandestine learning" (BîRLEA 1983:12-13).
}

With some local particularities, similar situations are attested to all over Europe and Asia (see KõIva 1996; PASSALIS 2011; RoOPER 2009; SMALlWoOd 2004).

Knowledge as a source of power

Although Babu seemed to have the upper hand (as head of the mountain and employer), the situation changes when they display their magical and therapeutic abilities. Therefore, social hierarchy is not the same as the ritual one: Ion's boss becomes his subordinate, asking for access to the sacred knowledge, access which is finally denied.

The transmission of a charm is in itself a ritual articulated on an initiation structure, the success of which depends on observing the rules and on the vocation or talent of the apprentice.

In our narrative, these are highlighted by the following contexts, in which D. S.. hopes to receive the words: a) in consecrated space: on the road - Walking on the road... space of liminality and transition, similar to an initiation ritual - and on the high mountain area, away 
from inhabited places, an area which in this case is the pasture level for all the sheep, even for the barren ones; $b$ ) without any witnesses (D. Ș. sends the other shepherds to follow a different path); c) within the professional pastoral community; d) from man to man.

D. S. seems to have the qualities necessary for a receiver of the charm, sensing the hidden, covert side of Ion's personality - I saw this guy knows something - thus activating the abilities favourable to sacred communication: enhanced attention, the ability to listen, to hear and to understand (closely connected with this requirement can be placed the strategy of whispering the charm, barely audible to the untrained ear), to memorize (the charm must be learnt after being heard for the first time). Being alert and on the prowl are the conditions for initiation that Babu tried to fulfil. Yet, we still do not know why Ion does not say anything (or he might have said something, but was not heard?!), refusing to teach D. S.. the words. We already know that stealing the words of the charm is one of the fundamental conditions for preserving the magic power and must be observed by both the one who has the sacred verbal structure and the one who receives it. However, Babu forces the rule and makes the mistake of requesting the charm - he asks for the secret of knowledge - explicitly and insistently. Consequently, Ion's reaction is prompt and violent. The power given by the sacred knowledge comes not only from knowing the unique verbal or gesture elements, but also from being aware and observing the rules which articulate the updating and transmission process, by ritually performing the structure. Without the latter elements, communication (horizontal, between the two people, and vertical, with the numen) remains incomplete and the initiation fails.

Therefore, even if he proved to have some special faculties that could recommend him as a charm receiver, $B a b u$ was denied the special status of somebody who knows the requested verbal structure. The appearance of the snakes functions as a warning, blocking D. S..'s access to a path he was not destined to be on (as the serpents' barrier may be decoded).

However, apart from the frame of unsuccessful magical initiation, what happened during the ritual confrontation influenced D. Ș.'s further social and professional identity: as a good shepherd and a leader, he was supposed to be able to take care of the flocks, a responsibility that meant, alongside other duties, protecting them from magic intervention and, if necessary, annihilating the influence of such attacks. "You cannot be a sheep breeder if you don't know the sheep. Only by looking at a sheep, you must know what remedy to give. (...) And if they were barren, blood would stream out. And if you didn't know what to do, they would all die."

We conclude that for $B a b u$, healing animals (combining empirical techniques, plants and magic practices, if necessary) is not valuable only in itself, but is also a component of pastoral science which gives professional fame and recognition.

Therefore, his entire career was marked by this failure: D. S. will not know how to protect the barren sheep from the terrible magic attack which brings death. If needed, he will not be able to integrally respect either his position as head of the mountain, or his trade; his competencies will be shadowed by fragility.

This is the reading key in which his self-image was altered and he needed an excuse focused on his opposing attitude: Ion did some devilish things. Since then, I've had no interest in charms. The refusal of magic will define the religious character of his healing acts. Significantly, he also emphasized it: "It's God who heals with His power, not me. 
(...) My parents taught me never to steal anything ${ }^{3}$ and always believe in God. And with these two, you can go further. Make the sign of the holy cross and all devils will run away."

\title{
3. Babu as knowledge deliverer
}

Any kind of knowledge works as a process and system among the components of the same information corpus (open!), thus giving rise to fluent cohabitation relations which are centripetal, in the case of a balanced structure. The integrative quality of knowledge, configured by the interdependence of many ideas and reality domains, does not imply the absence of contradictions in data, approaches and principles.

What D. S. knows goes beyond the domain of healing. We artificially limit our approach to the healing element, considering that even when he tells a story or applies some empirical medical knowledge, his whole information repertoire (including the supernatural characters and religious narratives) is re-evaluated and somehow updated. Trying to slightly and relatively improve the fragmentation resulting from the material selected above, in the next phase of our analysis, we will consider other segments of this interview. In this wider context, to whom, how and how much does D.Ş hand down his secrets?

I. Within his family, to his own offspring:

\begin{abstract}
"We have children. I took them to the mountains to show them the plants, but they don't want to deal with this. They started in this, and they ran away. (...) When the rain started, I have two grandchildren, I told them: 'Come, the times are changing. (...) I'll break them in, eventually: I'll die and you'll be asked: whose son are you? Ș.'s. Well, your father knew many things. What do you know?"”
\end{abstract}

His son is a vet, not interested in his father's empirical therapy. (We will return to this detail).

II. Within the local professional communities, to an apprentice. In fact, he did not mention anybody who had taken over his profession, with everything it entails, including therapeutic competencies, empirical or magic.

III. Within the context of the interview, to the foreigner, who becomes a link in the process of oral transmission and the first source in branching out the first network, thus spreading the formalized information outside its natural frame, towards new contexts which will articulate the second life of the charm. I was part of this third situation and therefore I have an internal view on it, useful for analysing the meta-cultural expressions and para-textual functions of D. S.'s memorate. These appeared as a result of the narrator's interaction with the listener, of the effort to captivate the researcher, not only in the dialogue, but also in the narrated experience, with consequences on the final form of the folkloric document and on the meanings it is given.

The reasons a story teller narrates a certain story differs from one situation to another and they are part of the integral message. In this regards the question is: what we think about $B a b u$ 's reasons to tell us the story with Ion.

\footnotetext{
${ }^{3}$ Is this a possible allusion to the very magic practice of stealing the sheep' milk?
} 
I participated in the interview having different hypostases of $m y$ multiple identity: ${ }^{4} \mathrm{I}$ asked, answered, reacted like an outsider, a possible patient, an investigator, a tourist, a (younger) woman talking with a (older) man, and, in fact, mainly like a field folklorist researcher. From all these facets there is one that is missing: the real professional and magic follower of D. Ș. Still, I do not know which of these $B a b u$ was dominantly addressing. At his turn, he asked questions, gave answers and reacted as a shepherd, a church singer, an old man, a local person, a bearer of pastoral traditions, a healer, and an owner of charms (charms other than the one he requested from Ion).

As I have already mentioned, the interview was not reduced to healing or incantation topics, although their weight was consistent. While being asked about the charm against evil eyes, indirectly but suggestively enough, he mentioned that we should not talk about it. Babu observed the requirements of keeping the spell undisclosed, using different strategies (similar to those that Ion used when D. S.. was insisting): explicitly refusing to say the spell (You see, not all secrets can be disclosed), elusively delaying the answer with equivocal words or simple sounds ( $\mathrm{Mmmm}$ ), denying his own competence (I don't know anything) or even miming incompetence and subordination to the one who asks (You know better than me), and, not least important, telling narratives. It was not a coincidence that he inserted the serpents' episode immediately after my questions about the evil eye charm formula. Babu used this story about the barrier of snakes, which prevented him from stepping forward (to continue his initiation) as a warning addressed to $m e$ ! He stopped me from asking more questions. Thus, he acted according to the main requirement of the ritual mechanisms of transmitting this folkloric category, namely keeping the secret. Moreover, he considered $m e$ a possible applied receiver of the charm, which from his point of view does not lose its sacred power when recorded. (It would have lost its efficiency only when uttered in improper conditions).

As for me, I used persuasive strategies (e.g. whispering, speaking as a presumptive patient) for making him say the words, but totally ignored the ritual conditions of the charm performance or its hidden quality, requirements that I had read about in books and archive documents but did not apply during field work (probably because I was interested in words only as a folklorist and not as a charmer seeking their ritual efficiency).

However, Babu was the one in possession of the knowledge - not only sacred, but integral - I was interested in. He skilfully used his authority, feeling entitled to test me with regards to the level of knowledge and familiarity with the very questions we were speaking about, but also as to how bright I was. To his challenging questions (which were not the result of his real need to be informed, but a manner to express his superiority), my elusive, truncated and undertone answers were - up to a point - strategies similar to those he also used with me, and which Ion had used with him. In a way, I behaved as a bearer of the undisclosed knowledge, as the keeper of the secret, although I had no secret, being just a folklorist doing fieldwork, miming her ignorance and negotiating her position, declining her own knowledge (I must confess I could have answered some of his questions) or, on the contrary, uttering it in a controlled manner, in accordance with the principle of field work which states that the researcher should not induce or influence the interviewees' answers, but at the same time trying to obtain as much data as possible from them.

\footnotetext{
${ }^{4}$ According to DéGH 1994:7.
} 
Both of us were involved in creating a narrative whose message was shaped by overlapping the subjective component of the very content of the story on the subjective meta-narrative and emotional components of the performing context. The latter cannot be archived but leaves its mark on the final form of the field document. Finally, $I$ took on my own insider's involvement, becoming a second hand story teller.

In the end, I coped honourably with D. Ș.'s challenges - "Well, my lady, you made me confess as you wished!" - listening to a set of narratives with supernatural characters, remedies, shepherding routs - topics which mainly interested me - yet not recording any charms.

\section{ASSESSING KNOWLEDGE, THE OLD TRADITION AND THE NEW WORLDS}

Moving on with the topic analysed above, every time I answered I don't know, D. S,. would reply: But what do you know? What have you learned from your books?, rhetorical questions whose real message was to oppose the empirical, vernacular knowledge, which also integrates an obsolete numinous component, represented by himself, to the modern, theoretical or applied sciences, represented by his urban audience and ... by his son, the vet: "I asked him: what do you know? And he says: 'I give them injections.' 'You give them injections, but with what?' (...) He has to know the herbs, the ones good for remedies, the poisonous ones!"

Following a different path, although a therapist himself, his son strays from the old practices and, more importantly, rejects his father's knowledge. At his turn, as he belongs to older times, D. Ș. has to redefine his authority status and reassess or adjust the traditional expressions of therapeutic knowledge from a modern perspective. He did not give up the healing practices; he did not turn to allopathic medicine, but found his niche: alternative medicine and the press.

Returning from the field, I was surprised to discover D. Ș.'s name on the internet. Journalists working for Formula As magazine ${ }^{5}$ had visited him and he had shared with them many of his autobiographic narratives, legends, beliefs and remedies (including his confrontation with Ion!), which he also told us in 2014. Reading the four articles published between 2002 and 2012 (APOSTOL 2009; no author 2006; ȚEPOSU 2002; ȚURCANU 2004), which have also been republished by some blogs, we noticed the high formalization of narratives, probably a consequence of repeating them in contexts which D. S.. considers similar: to an ethnologist or journalist, and therefore the information is given to an outsider who takes it and spreads it. He probably considered us as sort of journalists. In both situations, the other lives of folklore can be found in nuce. The one in the research archives gives a context for scientific documents which intend to reflect a segment of reality as impartially and as neutrally as possible and represents an authority centre for reading cultural phenomena. The other one is represented by the very manner in which folklore is taken, adjusted and spread by mass media.

\footnotetext{
${ }^{5}$ A New Age magazine well known to the Romanian public.
} 
The information newspapers and magazines publish follows the reasons and priorities triggered by the characteristics of literary journalism or by the policy of each publication. In the case of Formula As magazine, we are (also) referring to promoting green medicine, ${ }^{6}$ considering itself the successor of the old tradition, followed (but on different coordinates!) by Babu himself. This time, however, the tradition represented by D. S. acquires a mystic aura, re-valued and adjusted by the journalists' pens.

Although closely linked with our topic, an analysis of the newspaper texts dedicated to D. S. (focusing on their connections with the illustrated reality and the rules observed when publishing a document) would exceed the length of the present study. However, we would like to highlight the impact of journalists' inquiry on the evaluation of the traditional knowledge and on the informant's self-perception. In other words, the previous meeting between D. S. and the journalists influenced our own meeting with the informant and, mainly, the narratives he decided to share with us.

Turning him into an invented character, the semi-fictional texts describe $B a b u$ with elements taken from the stereotyped portrait of the archaic shepherd: "For him who has spent his life in the wilderness, God is the closest. He can see God, he can talk to God anytime he wants" (APOSTOL 2009). "At 81 years old, after an entire life spent on the top of the mountain, with the sheep, he knows the rules of the seen and of the unseen world, as if he stays on the right side of God" (Apostol 2009). Released from the influence of the sacred, the secret, which is no longer meant to be kept or ritually transmitted, becomes an exotic mark of the past and of tradition, in fact, fuelling a new myth of authenticity, convenient for legitimating new religious and spiritual movements: "The world seen by $B a b u$ is a special, secret world, a world that he learnt to understand by listening to it" (APOSTOL 2009).

\section{REFERENCES CITED}

Apostol, Cătălin

2009 Babu, împăratul munților (Babu, the Emperor of the Mountains). Formula As 871. http://www.formula-as.ro/2009/871/societate-37/BabuBîrLEA, Ovidiu imparatulmuntilor-11182 (accessed March 14, 2015).

1983 Folclorul românesc. Momente şi sinteze [Romanian Folklore. Issues and DÉGH, Linda Synthesis]. II. Bucharest: Minerva Publishing House.

1994 American Folklore and the Mass Media, 7. Indiana University Press. HonKo, Lauri

1998 Memorates and the Study of Folk Belief. In Kvideland, Reimund - K. SEHMSDORF, Henning (eds.) Nordic Folklore. Recent Studies, 100-109. Indiana University Press.

\footnotetext{
${ }^{6}$ The alternative medicine magazine issued by the same editorial office is Asul verde.
} 
KõIVA, Mare

1996 The Transmission of Knowledge among Estonian witch Doctors. Folklore: Electronic Journal of Folklore, vol. 2. December. http://www.folklore.ee/ folklore/vol2/docdoc.htm (accessed June 1, 2017).

MARIAN, Simion Fl.

1875 article without title in Familia IX(31):357-362.

Passalis, Haralampos

2011 Secrecy and Ritual Restriction on Verbal Charms Transmission in Greek Traditional Culture. Incantatio. A Journal of Charms, Charmers and Charming. http://www.folklore.ee/incantatio/Incantatio_2011_1_Passalis.pdf (accessed June 1, 2017).

Prut, Constantin

1972 Fantasticul în arta populară românească [The Fantastic in Romanian Traditional Art]. Bucharest: Publishing House Meridiane.

ROOPER, Jonathan

2009 Charms, Charmers and Charming: International Research on Verbal Magic. Palgrave Mcmillan.

SMALlWOOD, T.M.

2009 The Transmission of Charms in English, Medieval and Modern. In Rooper, Jonathan (ed.) Charms and Charming in Europe, 11-31. Palgrave McMillan.

T,EPosu, Otilia

$2002 \mathrm{Cu}$ oile printre stele [With Sheep among the Stars]. Formula As 536. http:// www.formula-as.ro/2002/536/acasa-1/acasa-3590 (accessed March 14, 2015).

T,URCANU, Horia

2004 Babu, Înțeleptul din Gura Râului [Babu, the Wise Man in Gura Râului]. Formula As 623. http:/www.formula-as.ro/2004/623/societate-37/Babu(no author) inteleptul-din-gura-raului-5170 (accessed March 14, 2015).

2006 Leacuri ciobănești din Mărginimea Sibiului [Shepherds' Remedies in Mărginimea Sibiului]. Formula As 725. http://www.formula-as.ro/2006/725/ medicina-naturista-25/leacuri-ciobanesti-dinmarginimea-sibiului-7139 (accessed March 14, 2015). 
Laura Jiga Iliescu is a senior researcher at the "Constantin Brailoiu" Institute of Ethnography and Folklore of the Romanian Academy (Bucharest) and member of the "East-West" Research Group at the HAS RCH Institute of Ethnology (Budapest). Since 2015 , she has served as visiting professor at the University of Bucharest. She graduated from the University of Bucharest in 1996 with a degree in philology, then obtained her doctoral degree at the Romanian Academy and the University of Craiova in 2004. The main domains of her interest are: interaction between oral and written cultural expressions in Europe in the early modern era; traditional, modern and virtual religious narratives, rituals and practices; mountain culture; oral performance; fieldwork techniques. She is the author of many Romanian and English-language research articles, as well as two books: Răsplata paradisului. Cărţi populare şi folclor în cultura tradiţională românească (The reward of Paradise. Popular books and folklore in Romanian traditional culture), Bucharest, 2006, and Structuri mentalitare carpatice. Naratiuni, ritualuri, habitat la comunităţile locale (Carpathian cultural patterns. Narratives, rituals, habitat in local communities), Bucharest 2013. She has co-authored two books: Scrieri ţărăneşti. Documente olografe aflate în AIEF (Peasants' writings. Documents stored in AIEF), Anthology by Laura Jiga lliescu, Anca Stere, and Cristina Neamu, Bucharest, 2004, and Oameni şi fiare. Introducere în universul imaterial al făurăriei / Men and irons. Introduction to the immaterial universe of ironsmithing, Romanian-English edition, Bucharest, 2011. Presently she is preparing a book about Christian rituals performed by Carpathian shepherds. E-mail: laura.jiga.iliescu@gmail.com 